\title{
Non-Finite Constructions in Time Clauses
}

\section{Erjon Agolli}

\author{
University of Tirana, \\ Faculty of Foreign Languages, \\ English Department \\ agollierjon@yahoo.com
}

\section{Doi:10.5901/mjss.2013.v4n11p406}

\begin{abstract}
What is the syntactic status of non-finite constructions in English and Albanian? Are they considered as clauses? And, what is more, when carrying temporal meaning, can we classify them as non-finite clauses of time? Non-finite constructions, which are sequences of words that lack a finite verb, have attracted the attention of English and Albanian grammarians. Due to the variety of structures and semantic relations triggered by them, non-finite constructions stand in a thin line between phrases and clauses. While many modern English grammarians treat them as clauses, Albanian grammarians give relatively controversial comments on their status. In addition to the status of non-finite constructions, this paper aims at identifying the major semantic relations expressed by them, analyzing examples from a corpus taken from "The Da Vinci Code" by Dan Brown, where time clauses make up about 20.000 words. Comparing the examples from the original text to their counterparts from the Albanian translated version will offer a new prospect on the peculiarities of non-finite constructions in time clauses.
\end{abstract}

Keywords: non-finite, time clause, semantic relations, syntactic status

\section{Introduction}

In the study of complex sentences with time clauses, the use and status of non-finite constructions are of special interest for the grammarians of English and Albanian. Because non-finite constructions present a variety of structures and semantic relations, maybe more than finite clauses of time, the boundaries of the sentence are somewhat unclear at this point. However, according to Miller's definition, which is in line with that of other English grammarians, "non-finite clauses are sequences of words which lack a finite verb but nonetheless are treated as subordinate clauses" (Miller, 2009):

(1)

a. While sitting at the table, Captain Wentworth wrote a long letter to Anne.

b. (Duke qëndruar ulur në tavolinë, Kapiten Uentuorthi i shkroi një letër të gjatë Anës.)

Among the reasons Miller gives for treating non-finite constructions as subordinate clauses, we can mention:

1. Non-finite and finite verbs have the same modifiers, i.e. like finite verbs, non-finite constructions can be followed by objects, complements, adverbials, etc.

2. They can have a subject

3. Some non-finite clauses express aspect (perfect, or progressive)

4. They do allow some modality to be signalled (necessity, permission, ability, etc.)

Quirk (1972) claims that non-finite clauses are means of syntactic compression in which the verb, an 'ing', 'ed', or 'to infinitive', functions as predicate and the subject is omitted. It is assumed that the subject can be treated as recoverable from the context, namely from within the same complex sentence, having the same reference as a noun or pronoun in the main clause. In addition, non-finite clauses, just as finite and verbless clauses, can express semantic relations of time, condition, concession, purpose, reason, and manner in a complex sentence (Popa, 2008).

On the other hand, Albanian grammarians recognize some non-finite constructions as expressing temporal relations, but they hesitate to classify them as clauses. Instead, they consider them as "functionally synonymous" with subordinate clauses of time (Akademia e shkencave, 2002). According to Totoni (2012), these constructions are part of the verb paradigm, because they denote an action or a state as process, and have grammatical diathesis (voice), but they are different from other verbs because they don't have the grammatical categories of mood, tense, and person. The first two features, the meaning and the category of voice, make these constructions be organized as clauses, but the lack of the other features, which are the basic components of the meaning of the sentence, drifts these constructions away 
from the clauses and joins them with the sentence elements. What is more, Çeliku (2012) argues that non-finite forms in standard Albanian cannot make a predicate, cannot have a different subject of their own, and they generally function as sentence elements. The noun ligji in (2) below is not considered by him as a subject but as "essential semantic compliment of the verb", and the verb has no grammatical indicator of agreement with the noun:

(2) $P a$ dalë ligji, ata nuk u besojnë fjalëve.

In this context of controversial ideas in the previous literature, this paper attempts to rich a conclusion on the status of non-finite constructions in the Albanian language, as well as to identify the Albanian equivalents of English nonfinite clauses of time and make a semantic-structural classification of them.

\section{Materials and Methods}

The corpus taken into consideration for the examples and analysis in this paper comprises some 40 non-finite clauses of time out of a total 870 complex sentences with time clauses extracted from the novel "The Da Vinci Code" by Dan Brown, comparing these examples to their counterparts from the Albanian translated version.

All complex sentences with non-finite clauses of time found in the original text and in the translated one were used to create an electronic corpus in order to facilitate their study in this, and in further research. Non-finite constructions were classified according to the semantic relations they express, the conjunctions used to present them, and their structural properties. In addition to providing natural language examples to illustrate certain theoretical points, the analysis of these data has led to very valuable findings on the most common non-finite constructions used in English, as well as on identifying the equivalent structures in the Albanian language.

\section{Results and Discussions}

In the corpus, I identified five main structures of non-finite constructions, namely before + -ing, while + -ing, after + -ing, since +- -ing, and until $+-i n g$. The most frequently used structures are while +- ing with $31 \%$, before +- -ing with $28 \%$, and after + -ing with $23 \%$. Non-finite constructions like since + -ing, and until + -ing are apparently less common.

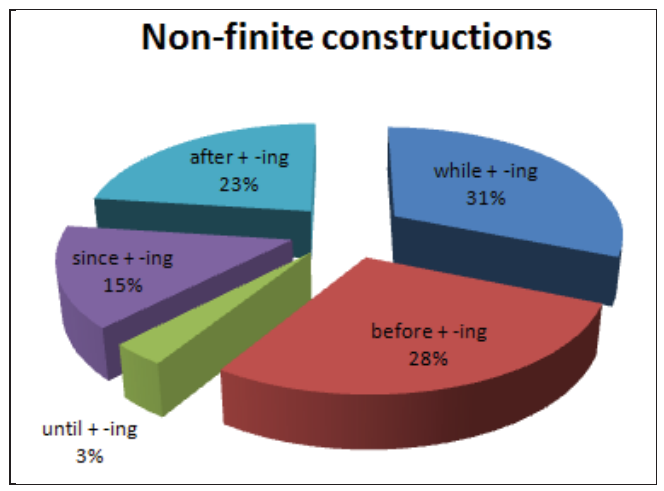

Fig. 1. Distribution of non-finite constructions in the corpus

For study purposes, non-finite constructions of time have been further classified into three main groups, taking into consideration the temporal relations expressed by these constructions in English, and by their Albanian counterparts:

\subsection{Non-finite constructions of anteriority}

The first group consists of a non-finite construction that is very common in the complex sentence with time clauses in English, the structure before + -ing, and until + -ing, which is less frequently used:

(3)

a. Lieutenant Collet, you will wait for me to arrive before taking action. (Brown, 2003)

b. Toger Kole, mos bëj asgjë pa ardhur unë! (Brown, 2006) 
In the example above, the structure of the subordinate clause in English is conjunction + non-finite construction + object, while we can notice that even though the subject is not expressed in the subordinate clause, it is understood to be you, given in the main clause. The non-finite construction before + -ing expresses temporal relations of anteriority and, in the Albanian language, it is equivalent to the non-finite construction of the type: përcjellore mohore (pa bërë). The use of the non-finite form with temporal meaning pa bërë, "which is often followed by a noun in the nominal case (more rarely by a pronoun or noun phrase) in the position of the subject" (Çeliku, 1986), shows that the action expressed in the main clause occurs before the action in the time clause. Indeed, as we can see in (3b), the structure of the translated version is non-finite construction + subject, where the subject of the non-finite construction is different from the subject in the main clause.

The use of a non-finite construction without a subject is a very common phenomenon in English and Albanian, and this absence of the subject has no deficiency in meaning whatsoever because both the subject and the tense are assigned in the main clause. Compare the structure and the semantic content of the non-finite construction in (4a) to the finite subordinate clause of time in (4b):

(4)

a. Before entering, she gazed reluctantly farther down the hall, twenty yards or so, to the spot where her grandfather's body still lay under the spotlight. (Brown, 2003)

b. Even before Sophie entered, though, she knew she was missing something. (Brown, 2003)

While the semantic content of the subordinate clauses in the examples above is the same, the only obvious difference is in their structure. In addition to the non-finite construction, and the time clause illustrated in (4), English and Albanian distinguish another structure expressing temporal relations which is even more frequently used, the phrase. Now, let's study the distinctions among these three possible structures in order to better evaluate the status of non-finite constructions in both languages:

(5)

a. I bore you from the womb before the start of the day. (Time adverbial)

b. I bore you from the womb before starting the day. (Before + -ing)

c. I bore you from the womb before I started the day. (Time clause)

(6)

a. Të kam lindur nga barku im para fillimit të ditës. (rrethanor kohe)

b. Të kam lindur nga barku im pa filluar ditën. (përcjellore mohore)

c. Të kam lindur nga barku im para se të filloja ditën. (fjali kohore)

Does the non-finite construction demonstrate more features of a phrase or clause? Avoiding giving a definite answer to this question at this stage, I will try to make a presentation of facts about English and then Albanian. First, the ing non-finite construction (5b) is similar to the time adverbial (preposition + noun phrase) (5a), in that the gerund in itself also carries nominal characteristics. Second, neither the non-finite construction nor the time adverbial has any indicator of agreement in number, case, etc. On the other hand, the similarities of the non-finite construction with the clause include: Both the finite (started) and the non-finite form (starting)denote action; they are both followed by an object, the day; the subject in the non-finite construction, even though unpronounced, is the same as that of the finite time clause, $\boldsymbol{l}$; the non-finite construction is presented by the time conjunction before, just like the time clause.

In Albanian, the non-finite form pa filluar, unlike the time adverbial, does not show any nominal characteristics and, while the time adverbial demonstrates synthetic means of agreement (the ending and particle of the genitive case), the non-finite construction doesn't. What is more, the non-finite construction in (6b) does not share many similar features with the time clause in (6c) either. The finite and the non-finite forms are followed by objects, but there is no time conjunction or agreement in the non-finite construction.

Another less common non-finite construction of anteriority is until + -ing in English and its Albanian counterpart sa + përcjellore mohore (sa pa bërë), which emphasize that the action in the main clause continues up to the moment when the action expressed by the non-finite form starts. See (7) and (8) below:

(7) Nonetheless, Christ's line grew quietly under cover in France until making a bold move in the fifth century, when it intermarried with French royal blood and created a lineage known as the Merovingian bloodline. (Brown, 2003)

(8) Ruaju sa pa u bërë e liga. (Akademia e shkencave, 2002) 


\subsection{Non-finite constructions of simultaneity}

Non-finite constructions like while, whilst, when + -ing, and when + - ed make up another important group expressing temporal relations in the English language, with while + -ing being the most frequently used non-finite form in the corpus:

(9)

a. He paused while working his fingers across the seam of his bedsheet, then continued. (Brown, 2003)

b. Heshti pak duke kaluar duart mbi palën e çarçafit, pastaj vijoi. (Brown, 2006)

a. Designed by Da Vinci in 1495 as an outgrowth of his earliest anatomy and kinesiology studies, the internal mechanism of the robot knight possessed accurate joints and tendons, and was designed to sit up, wave its arms, and move its head via a flexible neck while opening and closing an anatomically correct jaw. (Brown, 2003)

b. Mekanizmat e brendshëm të kalorësit, që Leonardoja i kishte vizatuar në vitin 1495, kur studionte së pari antominë dhe lëvizjen, kishin nyjë dhe muskuj të punuar me shumë kujdes: mund të ulej, të lëvizte krahët dhe kokën falë qafës së përthyeshme dhe të hapte e të mbyllte nofullat, që ishin të përsosura nga pikpamja anatomike. (Brown, 2006)

Going back to the issue of the status of non-finite constructions, let's study the example above in the light of Miller's theory in treating them as clauses. We can say that the non-finite construction in (9a) is followed by an object (his fingers) and an adverbial (across the seam of his bedsheet), expresses progressive aspect, and has an understood subject $(\mathrm{He})$. These are sound reasons to treat non-finite constructions in English as clauses.

As far as the subject is concerned, since the subject of the dependent clause is the same as that of the main clause, it is left out to avoid repetition - although this is an unusual phenomenon for finite clauses of time in English, which never have missing subjects. However, Newson (2006) claims that non-finite clauses do not lack subjects at all, they simply do not have pronounced subjects. One argument in favor of this assumption is that one absent subject ought to be exactly the same as another absent subject and only if they are present could they possibly differ from each other. In (10a), the subject (the internal mechanism of the robot knight) is only mentioned in the main clause and is not pronounced in the preposed -ed non-finite clause and in the postposed -ing non-finte clause of time. In other words the main clause must begin with the subject that performs both the action in the main clause and that in the non-finite clause, otherwise the sentence would be ungrammatical:

(11)

a. While telling Sophie about the Knights Templar, this key, in addition to having the Priory seal embossed on it, possessed a more subtle tie to the Priory of Sion.*

b. While telling Sophie about the Knights Templar, Langdon had realized that this key, in addition to having the Priory seal embossed on it, possessed a more subtle tie to the Priory of Sion. (Brown, 2003)

Example (11a), which is grammatically incorrect, gives the subject of the main clause (this key), but it is not the doer of the action in the non-finite clause of time, which is why it is unclear who was telling Sophie about the Knights Templar - definitely not this key! In (11b), on the other hand, the subject (Langdon) placed at the beginning of the main clause expresses the person that performs the action denoted by the verb realized in the main clause and that denoted by the non-finite construction telling in the dependent clause.

Meanwhile, in the Albanian language, the subject can be present as in (3b), or it can be missing and be understood by the use of endings and other synthetic means. Thus, even though the subject in (9b) above is neither placed in the main clause nor in the dependent clause, it is understood to be $\mathrm{Ai}(\mathrm{He})$ due to the context outside this complex sentence and the use of the -i ending in the finite verbs heshti and vijoi.

The non-finite construction of the type duke bërë (përcjellore), which is the Albanian counterpart of while + -ing, is considered by the Albanian grammarians as "synonymous with the time clauses of simultaneity in the functional point of view" (Akademia e shkencave, 2002):

(12)

a. Langdon had already made his decision several minutes ago, while standing alone at the window overlooking College Garden. (Brown, 2003)

b. Tek ishte duke parë oborrin nga dritarja, Langdoni kishte do çaste që e kishte ndarë mendjen. (Brown, 2006)

The temporal relations in the non-finite construction in $(12 \mathrm{~b})$ are strengthened by the use of the time conjunction tek, although non-finite constructions with temporal meaning in the Albanian language are typically not preceded by time 
conjunctions - a fact which sometimes makes the identification of semantic relations even more difficult since the same structure can also express other syntactic functions and relations. For example, the non-finite forms pa bërë and duke bërë in the following sentences expresses semantic relations of manner, not time: Zefi hyri pa u ndier. Ecte duke mbajtur bukën nën sqetull (Çeliku, 2010).

Similarly, if the time conjunction is left out in such constructions in English, the temporal relations are somewhat diminished, as compared to the cases when the non-finite -ing form is preceded by while:

(13)

a. Attempting to steal a case of cured ham from a cargo ship, he was caught by a pair of crewmen.

b. While attempting to steal a case of cured ham from a cargo ship, he was caught by a pair of crewmen. (Brown, 2006)

In addition to the above-mentioned structures, simultaneity in English can be expressed by the non-finite construction when + - ed, which in the Albanian translation of the corpus corresponds to the use of the participle (pjesore):

a. When diagrammed inside a circle, these thirty-two points of the compass perfectly resembled a traditional thirty-two petal rose bloom. (Brown, 2003)

b. Të vizatuara brenda një rrethi, ato tridhjetë e dy drejtime të busullës apo të erërave, i ngjanin një trëndafili me tridhjetë e dy petale. (Brown, 2006)

\subsection{Non-finite constructions of posteriority}

The third group of non-finite constructions used in English time clauses includes structures like: after + -ing, since + ing, and in isolated cases, upon + -ing, once + -ed ${ }^{1}$.

(15)

a. Since hosting the coronation of William the Conqueror on Christmas Day in 1066, the dazzling sanctuary has witnessed an endless procession of royal ceremonies and affairs of state-from the canonization of Edward the Confessor, to the marriage of Prince Andrew and Sarah Ferguson, to the funerals of Henry V, Queen Elizabeth I, and Lady Diana. (Brown, 2003)

b. Qysh kur në të u bë kurorëzimi i Uiliam Pushtuesit ditën e Krishtlindjeve të vitit 1066, abacia ka qenë dëshmitare e një serie të pafund ceremonish mbretërore dhe punësh të mëdha shtetërore, që nga kanonizimi i Eduard Rrëfyesit deri te martesa e princit Andrea me Sarah Fergusonin dhe te varrimi i Enrikut V, Elisabetës I dhe Lady Dianës. (Brown, 2006)

(16)

a. Fache, after finding Saunière's cryptic text on the floor, had uploaded photographs of the entire crime scene to the Cryptography Department in hopes someone there could tell him what the hell Saunière was trying to say. (Brown, 2003)

b. Fashi, mbasi kishte zbuluar shkrimin misterioz mbi dysheme, kishte shkarkuar në kompjuterin e departamentit të kriptologjistë të gjjithë fotografitë e skenës së krimit, me shpresë se mos ndokush mund ti shpjegonte ç'kishte dashur të thoshte Sonieri. (Brown, 2006)

(17)

a. Despite the pall of trepidation that settled over him upon seeing the words, Langdon told himself this was good news. (Brown, 2003)

b. Sado që ishte diçka shumë shqetësuese, Langdoni e gjykonte një lajm të mirë. (Brown, 2006)

As we can see from the above examples, the non-finite time clause can come before (15a), in the middle (16a), or after (17a) the superordinate clause.

However, what I would like to focus on is the fact that non-finite constructions after + -ing, and since + -ing denote posteriority in the general sense, and are synonymous with the Albanian finite clauses of time with the conjunctions pasi/ mabasi, and qysh kur/që kur, which is why the Albanian translation in each case uses a finite clause of time, instead of a

IIn addition to the term non-finite clause, some grammarians of modern English such as Randolph Quirk, Sidney Greenbaum, etc. also use the terms adverbial -ing clause of time, and adverbial -ed clause of time. 
non-finite one. Albanian non-finite constructions of posteriority një të bërë and me të bërë, on the other hand, denote actions immediately following each other and are closer in meaning to the English finite time clauses with the conjunctions as soon as, once. "The non-finite construction of immediate posteriority me të bërë can be followed by a noun or pronoun in the nominal case in the position of the subject: then we can treat it as a clause (Akademia e shkencave, 2002):

(18)

a. Me të arrdhur shoferi, do të nisemi për në Durrës.

b. Një të dëgjuar që u trembën shqerrat në mezhdë, la delen e hodhi në qafë çorapen.

Çeliku (2010) claims that non-finite constructions of the type me të bërë, and një të bërë cannot be treated as clauses but as complex sentence elements. According to him, we can talk of non-finite constructions equivalent to the clause only in some cases:

(19)

a. Një të vajtur në shtëpi, një të fjetur. (Two or more "gerund"-s)

b. Me të ardhur ai, ajo heshti. ("Gerund" followed by a nominal + finite form with a subject)

(20)

a. Sa vajti në shtëpi, fjeti.

b. Sa erdhi ai, ajo heshti.

The non-finite constructions in (19), which are synonymous to the finite time clauses in (20), describe two actions that immediately succeed each other in time.

\section{Conclusions}

In conclusion, we can say that non-finite constructions in complex sentences with time clauses are a very interesting linguistic phenomenon that deserves special attention not only by the grammarians of English language but also by those of the Albanian language. The crucial point in the study of non-finite constructions is definitely their status i.e. are there predicative relations between the components of non-finite constructions so that we can consider them as subordinate clauses, or these constructions function as a phrase?

While English grammarians agree on treating them as clauses, their classification in the Albanian language still remains a problem. On the one hand, Albanian traditional grammar treats them as subordinate clauses, and (Akademia e Shkencave, 2002) considers non-finite constructions as "functionally synonymous" with subordinate clauses.

On the other hand, the Albanian grammarian Mehmet Çeliku claims that these constructions function as complex sentence elements (non-finite form + a nominal in the role of time adverbial). To support his point, he argues that the relationship between the non-finite form and the nominal is mainly a semantic one, not a grammatical one. "The non-finite form is not grammatically dependent on the nominal case, while semantically the nominal case expresses the doer of the action, the subject, and functions as a modifier of the non-finite form. Thus, there exist reversed relations compared to the Subject-Predicate construction, where the predicate, as we know, modifies the subject" (Çeliku, 2010). Another argument that he uses to support his point, is the fact that these non-finite constructions in Albanian are not presented by subordinating conjunctions, which distinguishes them from subordinate clauses.

However, taking into consideration the main characteristics of these constructions in Albanian, and the basic grammar rules of the Albanian language as an inflectional language which, unlike English, requires agreement between the subject, the verb and other sentence elements, non-finite constructions should be classified neither as sentence elements nor as clauses. The non-finite form expressing temporal relations should simply be treated as another syntactic construction adding up to the existing traditional forms such as the adverbial of time or the subordinate clause of time. Thus, the temporal context of the main clause can be completed by a non-finite construction, just as it can be completed by an adverbial of time, or a dependent clause of time. Classifying non-finite constructions as a special separate category opens a new venue for further research on their peculiarities regarding the semantic-functional relations and structural characteristics.

\section{References}

Akademia e shkencave. (2002). Gramatika e gjuhës shqipe (sintaksa). Tiranë.

Brown, D. (2003). The Da Vinci Code. London: Bantam Press.

Brown, D. (2006). Kodi i Da Vinçit. (Shqipëruar nga Amik Kasoruho). Tirana: Dudaj.

Çeliku, M. (2012). Sintaksë e Gjuhës Shqipe (Përbërësit Sintaksorë). Tirana: ILAR. 
Çeliku, M. (1986). Kuptimet dhe Përdorimet Sintaksore të Trajës së Tipit pa punuar në Gjuhën e Sotme Letrare Shqipe. SF, Nr.3, p. 90114.

Çeliku, M. (2010). Format e Pashtjelluara të Foljes në Gjuhën e Sotme Shqipe. Tiranë: shblu.

Miller, J. (2009). An Introduction to English Syntax (Second Edition). Edinburgh: Edinburgh University Press.

Newson, M. (2006). Basic English Syntax with Exercises. Budapest: Bolcsesz Konzorcium HEFOP Iroda.

Popa, E. (2008). Non-finite and Verbless Clauses: Textual Values. RRL, LIII, 3, p. 329-339.

Quirk, R., et al. (1972). A Grammar of Contemporary English. London and New York: Longman.

Totoni, M. (2000). Fraza me nenrenditje. Tirana: SHBLU.

Totoni, M. (2012). Sintaksa e Gjuhës Shqipe (Fraza e Përbërë). Tirana: Arbëria. 